\title{
The geology of the Liqhobong Main Pipe kimberlite
}

\author{
Mafusi Rapopo', Paul Sobie ${ }^{2,3}$, Paul Bosma ${ }^{1,3}$ \\ ${ }^{1}$ Liqhobong Mining Development Company, Butha Buthe, Lesotho, mafusie@gmail.com \\ ${ }^{2}$ MPH Consulting Limited, Toronto, Canada, psobie@mphconsulting.com \\ ${ }^{3}$ Firestone Diamonds plc, Cape Town, South Africa, pbosma@firestonediamonds.com
}

\section{Introduction}

The 8.5ha circular Main Pipe is the largest of six known kimberlites comprising the Liqhobong cluster which occurs along a strike of approximately $2.5 \mathrm{~km}$. The cluster is part of the larger WNW trending mid-late Cretaceous Lemphane - Robert (L-R) Kimberlite Belt occurring in north-eastern Lesotho. The Liqhobong kimberlites intrude Jurassic Drakensberg lavas and outcrop at $\sim 2650 \mathrm{~m}$ above sea level. The Drakensberg lavas cover more than two thirds of Lesotho and rise to an altitude of $3500 \mathrm{~m}$ above sea level with an estimated thickness of $1.5 \mathrm{~km}$, and are considered to be related to the breakup of Gondwana (Adelmann and Fiedler, 1996). The regional basement comprises Archean metasediments and metavolcanics of the Kaapvaal Craton.

\section{Geology of the Liqhobong Main Pipe}

The Main Pipe is a typical southern African diatreme with steep-sided walls abuting country rock basalt and is comprised of five lithofacies (K1, K2, K4, K5 and K6) distinguished in terms of variations in the matrix hardness, texture, magnetic susceptibility, degree of mantle sampling, dilution and alteration. More than $10 \mathrm{~km}$ of core in 60 holes has been studied. The pipe's lithofacies are mostly tuffisic (massive volcaniclastic) kimberlite breccias and marginally hypabyssal kimberlite. The deepest core hole was drilled vertically at the centre of the pipe and ended in a tuffisic kimberlite at $650 \mathrm{~m}$ below surface.

Kimberlite Indicator Minerals (KIMs) occurring as disaggregated xenocrysts are very rare but common as components of peridotite xenoliths. Olivine macrocrysts are conspicuous and more usefully indicative of degree of mantle sampling. All the lithofacies are universally diluted with Drakensberg fragments, and in two cases (K2 and K1) contain xenolithic evidence for intruding through the basement.

$\mathrm{K} 1$, a tuffisic kimberlite breccia (TKB) which comprises approximately $\sim 3 \%$ of the indicated resources (to $-180 \mathrm{~m}$ ) was exposed during the current mining activity in the NW quadrant of the Pipe. The K1 lithofacies forms a shallow wedge striking NE (Fig. 1), and is recognised by its clayey texture with distinctive highly altered brown basalt and basement xenoliths, moderately abundant olivine macrocrysts, copious carbonate veining and infrequent pelletal lapilli.

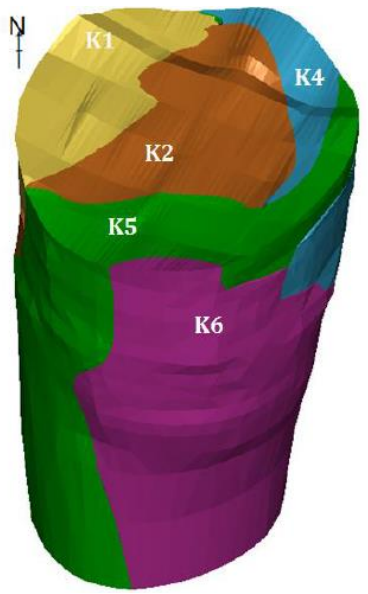

Figure 1. The different lithofacies of the Main Liqhobong Kimberlite Pipe. The pipe's surface diameter is $\sim 300 \mathrm{~m}$.

$\mathrm{K} 2$, the volumetrically most abundant lithofacies to $180 \mathrm{~m}$ depth, is also a TKB with internal variations in the quantities of crustal xenoliths, olivine macrocrysts, degree of alteration and magnetic susceptibility that makes the unit divisible into two sub-lithofacies (termed TKB1 and TKB2 by previous workers). Both sub-lithofacies are characterised by none to pervasive carbonate segregations and veining (Fig. 2a), dark to dark brown olivine macrocrysts (up to 25\%), $\leq 3 \%$ basement clasts, $10-30 \%$ basalt clasts and $\leq 7 \%$ peridotite xenoliths. Irregular, distinct localised areas with highly altered basement clasts as well as pockets with highly calcified or chloritised basalt (Fig. 2b) are present. The TKB1 and TKB2 sub-units are commonly 
interlayered and distinguished by typical strong magnetic susceptibility, comperativley more altered basalt clasts and lower quantities of pelletal lapilli in the former and weak to nonmagnetic susceptibility and abundant pelletal lapilli in the latter. Rocks transitional between TKB 1 and TKB 2 are present. It has not yet been established whether diamond grade varies between TKB1 and TKB2.

K5 outcrops in the southwest through to eastern parts of the pipe and constitutes $\sim 12 \%$ of the volume in the upper $180 \mathrm{~m}$ of the pipe, below which it becomes the volumetrically most abundant lithofacies at the expense of K2. The lithofacies is mainly a tuffisic kimberlite breccia (termed TKB3 in the past) with virtually no pelletal lapilli and basement xenoliths, weak to moderate magnetic susceptibility, distinctive small black or dark brown olivine macrocrysts (Fig. 2c) and the most abundant peridotite micro-xenoliths in the Main Pipe. There is minor sub-facies of K5, a more magmaclastic kimberlite (TK1), which has in contrast very minimal crustal dilution, is non-magnetic, and has abundant cream to pale or golden yellow (serpentinised) olivine macrocrysts and phenocryst. The olivine microcryst population in TK1 reaches up to $25 \%$. K5 generally has the highest diamond grade of the Main Pipe's lithofacies.

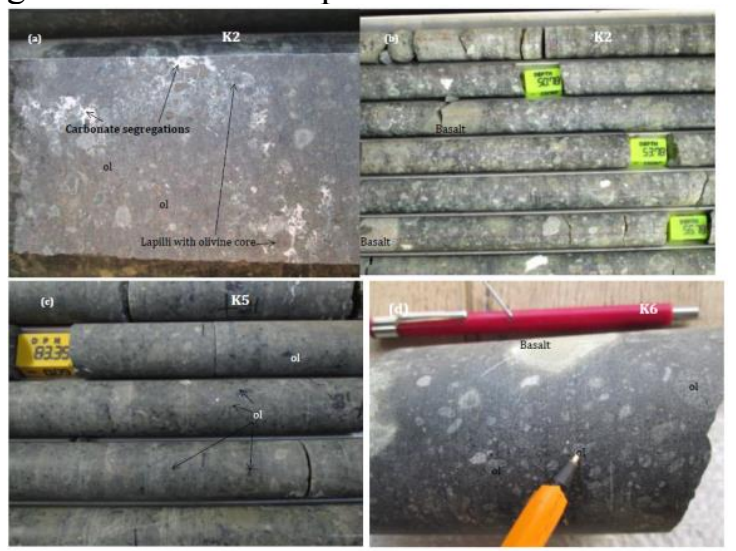

Figure 2. Drillcore samples of the selected lithofacies of the Main Pipe showing (a) carbonate segregations in K2, (b) greenish chloritised basalt clasts in $\mathrm{K} 2$, (c) numerous small black olivine macrocrysts in K5 and (d) numerous cream coloured fresh olivine macrocrysts in K6.

$\mathrm{K} 4$, a massive volcaniclastic kimberlite breccia constituting about $14 \%$ of the indicated resources, is characterised by a non- to weakly magnetic dark competent matrix, virtually no pelletal lapilli, moderately to highly serpentinised olivine macrocrysts and phenocrysts and infrequent prominent KIM xenocrysts. Although KIM xenocrysts (garnet, Cr-diopside and ilmenite) are broadly infrequent, they are comparatively more abundant in K4 than in any other lithofacies of the Main Pipe.

K6 constituting $4 \%$ of the indicated resources is differentiated by a strongly magnetic competent kimberlite matrix with abundant coarse-grained cream coloured olivine macrocrysts, no pelletal lapilli and no carbonate veining. Not only are the olivine macrocrysts in K6 fresh and uniquely cream in colour, but they are also commonly larger than $5 \mathrm{~mm}$ in size (Fig. 2d).

\section{Inter-lithofacies relationships}

The inter-lithofacies' contacts range from sharp to gradational. $\mathrm{K} 1$ abuts onto $\mathrm{K} 2$ at a sharp contact inclined from 10 to $30^{\circ}$ and in turn hosts K2 autoliths (Fig 3a). K2 has a sub-vertical gradational to indistinct contact with both $\mathrm{K} 5$ and $\mathrm{K} 4$, and there are some indistinct examples from drillcore where $\mathrm{K} 5$ autoliths are apparent in $\mathrm{K} 2$.

K4 in turn has a sharp contact with K5, with K5 overlying $\mathrm{K} 4$ at an apparent strike/dip angle of $332^{\circ} / 30^{\circ}$ in the NE to SE of the Pipe (Fig. 3). $\mathrm{K} 4$ autoliths are also found in K5. A somewhat curvilinear slickenside plane with strike/dip angle of $339^{\circ} / 82^{\circ}$ is positioned near the K4/K5
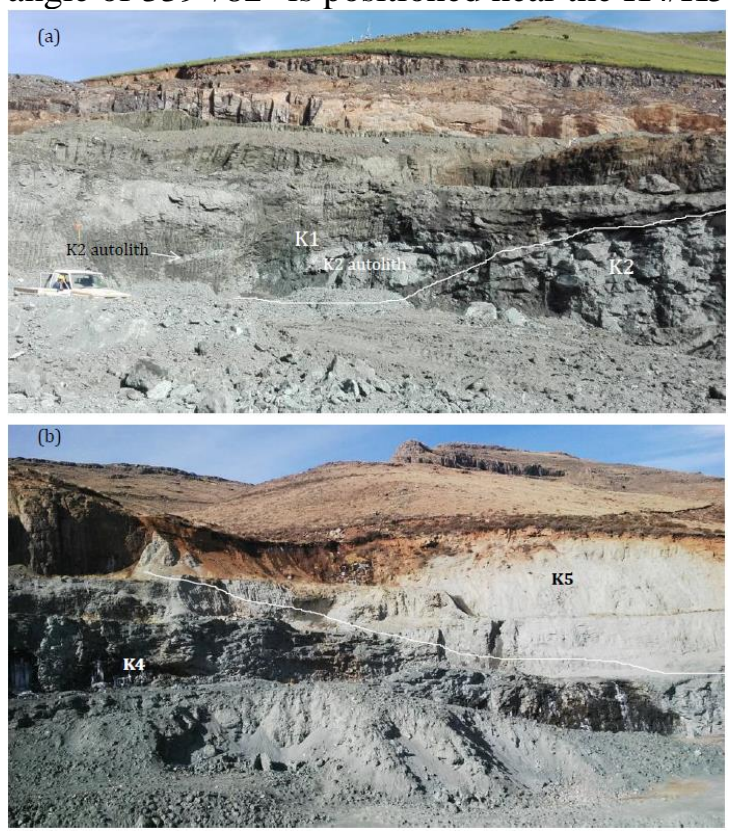

Figure 3. Contact relations between (a) $\mathrm{K} 1$ and $\mathrm{K} 2$ showing an inclined contact as well as K2 autoliths in $\mathrm{K} 1$ and (b) $\mathrm{K} 4$ and $\mathrm{K} 5$ with a clear matrix 
competence and colour difference between the two lithofacies on the same bench.

contact and more developed within the more competent K4 lithofacies.

K6 has a gradational contact with K5 in the south of the Pipe marked by a change in the colour and size of olivine macrocrysts and an increase in the magnetic susceptibility. Globular enclaves of K4 are found in K6.

From these sequences, it can be deduced that the intrusive order of emplacement is $\mathrm{K} 4>\mathrm{K} 6>\mathrm{K} 5>\mathrm{K} 2>\mathrm{K} 1$; the first two being largely more magmaclastic kimberlites and the last three being tuffisitic kimberlite breccias.

On average, the order of specific gravities is $\mathrm{K} 1<\mathrm{K} 2<\mathrm{K} 4<\mathrm{K} 5<\mathrm{K} 6$, ranging from 2.25 to $2.77 \mathrm{~g} / \mathrm{cm}^{3}$. The density sequence agrees with the overall abundance of olivine macrocrysts and, with the exception of K6 which has seen minor bulk sampling, mirrors the relative order of diamond grades. With all facies combined, the Main Pipe has an average $+1.25 \mathrm{~mm}$ grade of $23 \mathrm{cpht}$.

\section{Discussion}

There are numerous mutual similarities between the different lithofacies of the Main Pipe. Country rock basalts are universal in all the lithofacies while basement gneisses and schists are found mainly in $\mathrm{K} 1$ and $\mathrm{K} 2$ and very occasionally in $\mathrm{K} 4$ and $\mathrm{K} 5$. The basalt clasts range from fresh to highly altered in $\mathrm{K} 5, \mathrm{~K} 2$ and $\mathrm{K} 1$, whereas those in $\mathrm{K} 4$ and $\mathrm{K} 6$ are commonly fresh or minimally chloritised in K4. K2 and K1 lithofacies host generally dark brown to black olivine macrocrysts whereas those in $\mathrm{K} 4$ and $\mathrm{K} 6$ are cream in colour, unless serpentinised to golden yellow or greenish colour in K4. Both K2 and K5 have localised zones of basalt brecciation rich in carbonate matrix whereas the basalt breccia in K4 is generally 'dry'. K2 and K5 characteristically exhibit intra-lithofacies variations whereas each of K4 and K6 is fairly homogeneous.

From these observations and relationships, it appears that $\mathrm{K} 5, \mathrm{~K} 2$ and $\mathrm{K} 1$ are may be genetically related while the older $\mathrm{K} 4$ and $\mathrm{K} 6$ may also be related.

\section{Conclusions}

The gradational $\mathrm{K} 2 / \mathrm{K} 5, \mathrm{~K} 2 / \mathrm{K} 4$ and $\mathrm{K} 5 / \mathrm{K} 6$ contacts suggest near synchronous intrusions whereas the sharp $\mathrm{K} 2 / \mathrm{K} 1$ and $\mathrm{K} 4 / \mathrm{K} 5$ contacts suggest successive magma pulses.

The fairly dark and competent nature of the kimberlite matrix of $\mathrm{K} 4$ and $\mathrm{K} 6$, their unique cream coloured olivine macrocrysts as well as the presence of comparatively more abundant KIM xenocrysts in K4 suggest different magma sources and different routes to emplacement for $\mathrm{K} 4$ and $\mathrm{K} 6$ than for K1, K2 and K5.

Both K4 and K6 accounting for less than 15\% of the pipe volume are thought to represent earlier melts which either originated from low volume melts or are remnants of earlier pulses slumped into the later comparatively more fluidised K5 intrusion. The absence of K4 and $\mathrm{K} 6$ autoliths in the more fluidised $\mathrm{K} 2$ favour both $\mathrm{K} 4$ and $\mathrm{K} 6$ being slumped kimberlites of earlier pulses. The inclined contact between $\mathrm{K} 4$ and $\mathrm{K} 5$ suggests $\mathrm{K} 4$ likely represents a remnant of an earlier pulse. The more magmaclastic nature of $\mathrm{K} 4$ and $\mathrm{K} 6$, their generally similar olivine macrocrysts populations and kimberlite matrix suggest they could be related.

The overall similarity in the $\mathrm{K} 5, \mathrm{~K} 2$ and $\mathrm{K} 1$ lithofacies suggest that they represent similar magma sources which were distinguished by the difference in fluid budget. The $\mathrm{K} 5$ being younger than $\mathrm{K} 4$ and $\mathrm{K} 6$ was followed almost synchronously by the intrusion of more fluidised pelletal lapilli-rich K2. K2 and K1 appear to represent the most violent (e.g Brown et al., 2006) and fluidised intrusions, erupted at the mantle-crust interface incorporating basement clasts, with the more tuff-like clayey K1 culminating intrusive activity at the Main Pipe seen at this exposre level of the diatreme. Since the second youngest K2 and oldest K4 lithofacies show gradational contacts, it is more likely that all the lithofacies erupted at closely spaced times.

\section{References}

Adelmann D, and Fiedler K (1996). Sedimentary development of the Upper Ecca and Lower Beaufort Groups (Karoo Supergroup) in the Laingsburg subbasin (SW Karoo Basin, Cape Province/South Africa), Schriftenreihe der Deutschen Geologischen Gesellschaft 1: 88-89, Bonn.

Brown RJ, Tait M, Field M, Sparks RSJ (2006). Progressive enlargement and infill of a kimberlite pipe: K2 pipe, Venetia Kimberlite Field, Limpop Province, South Africa; In Proceedings of the International Conference, Saskatoon. 